\title{
Phenolic compounds in coffee ${ }^{1}$
}

\author{
Adriana Farah and Carmen Marino Donangelo*
}

Laboratório de Bioquímica Nutricional e de Alimentos. Departamento de Bioquímica, Instituto de Química, Universidade Federal do Rio de Janeiro, Cidade Universitária, CT, Bloco A, Sala 528-A. Ilha do Fundão, Rio de Janeiro, RJ, 21949-900, Brazil. *Corresponding author: donangel@iq.ufrj.br

Phenolic compounds are secondary metabolites generally involved in plant adaptation to environmental stress conditions. Chlorogenic acids (CGA) and related compounds are the main components of the phenolic fraction of green coffee beans, reaching levels up to $14 \%$ (dry matter basis). These compounds have a number of beneficial health properties related to their potent antioxidant activity as well as hepatoprotective, hypoglycemic and antiviral activities. The main groups of CGA found in green coffee beans include caffeoylquinic acids, dicaffeoylquinic acids, feruloylquinic acids, $p$-coumaroylquinic acids and mixed diesters of caffeic and ferulic acids with quinic acid, each group with at least three isomers. During coffee processing, CGA may be isomerized, hydrolyzed or degraded into low molecular weight compounds. The high temperatures of roasting also produce transformation of part of CGA into quinolactones and, along with other compounds, melanoidins. This review focuses on the chemical characteristics, biosynthesis, and distribution of CGA and related compounds in coffee. The influence of genetic, physiological and environmental factors as well as processing on the chemical composition of coffee beans is discussed. The impact of CGA composition of green coffee on cup quality is also approached. Despite the existence of substantial published information on the total levels of CGA in coffee, more research is needed on the composition of minor phenolic compounds and specific CGA isomers (and related substances) in green and roasted coffee beans, as well as their impact on coffee quality.

Key words: Coffea, chlorogenic acids, chlorogenic acid lactones, coffee quality, coffee processing, coffee roasting, quinides.

Compostos fenólicos em café: Os compostos fenólicos são metabólitos secundários de plantas envolvidos na adaptação a condições de estresse ambiental. Os ácidos clorogênicos (CGA) e compostos relacionados são os principais componentes da fração fenólica dos grãos de café verde, alcançando teores de até $14 \%$ (em peso seco). Estes compostos apresentam propriedades benéficas à saúde, não só devido à sua potente atividade antioxidante, mas também como agentes hepatoprotetores, hipoglicemiantes, e antivirais. Os principais grupos de CGA encontrados nos grãos de café verde incluem os ácidos cafeoilquínicos, dicafeoilquínicos, feruloilquínicos, $p$-cumaroilquínicos e ésteres mixtos dos ácidos cafeico e ferúlico com ácido quínico, com pelo menos três isômeros por grupo. Durante o processamento do café, os CGA podem ser parcialmente isomerizados, hidrolizados ou degradados a compostos de baixo peso molecular. As altas temperaturas observadas no processo de torrefação produzem também a formação de lactonas e a polimerização dos CGA com outros componentes do café para formar melanoidinas. Esta revisão aborda as características químicas, a biosíntese e a distribuição dos CGA e compostos relacionados nos grãos de café. A influência de fatores que modificam a composição dos grãos verdes, tais como genéticos, fisiológicos e ambientais, assim como o efeito do processamento sobre a composição de CGA do café são discutidos. O impacto dos CGA e compostos derivados sobre a qualidade da bebida do café é outro tópico abordado nesta revisão. Apesar da riqueza de informações na literatura relacionadas aos teores totais de fenólicos e CGA em café, mais investigações são necessárias no que diz respeito tanto à composição de isômeros específicos dos CGA, de seus derivados, e de outros compostos fenólicos minoritários presentes no café, quanto ao seu impacto sobre a qualidade da bebida.

Palavras-chave: Coffea, ácidos clorogênicos, ácidos clorogênicos-lactonas, procesamento do café, qualidade do café, torração do café, quinideos.

\footnotetext{
${ }^{1}$ This work is dedicated to the memory of our dear friend and mentor Prof. Dr Luiz Carlos Trugo for his outstanding contribution to coffee research and for guiding us into this exciting research field.
} 


\section{INTRODUCTION}

Phenolic compounds are ubiquitous constituents of higher plants found in a wide range of commonly consumed plant foods such as fruits, vegetables, cereals and legumes, and in beverages of plant origin, such as wine, tea and coffee (Cheynier, 2005; Manach et al., 2004). These compounds are secondary metabolites of plants generally involved in defense against ultraviolet radiation or aggression by pathogens. Several thousands of phenolic compounds have been described in plant foods and can be grouped into different classes according to their basic chemical structure (such as type and number of phenol rings), and into different subclasses, according to specific substitutions in the basic structure, association with carbohydrates and polymerized forms (table 1) (Manach et al., 2004). Most of these compounds have received considerable attention as potentially protective factors against human chronic degenerative diseases (cataracts, macular degeneration, neurodegenerative diseases, and diabetes mellitus), cancer and cardiovascular disease (Scalbert et al., 2005).

While condensed tannins are the main phenolic compounds in coffee pulp, in the seed, phenolic compounds are present predominantly as a family of esters formed between certain hydroxycinnamic acids and quinic acid,

Table 1. Main classes of phenolic compounds in higher plants.

\begin{tabular}{ll}
\hline Classes and sub-classes & Examples of specific compounds \\
\hline $\begin{array}{l}\text { Non-flavonoid compounds } \\
\text { Phenolic acids }\end{array}$ & \\
Benzoic acids & $\begin{array}{l}\text { Gallic acid; protocatechuic acid; } \\
\text {-hydroybenzoic acid }\end{array}$ \\
Hydroxycinnamic acids & $\begin{array}{l}\text { Coumaric acid; caffeic acid; } \\
\text { ferulic acid; sinapic acid }\end{array}$ \\
& Pentagalloylglucose \\
Hydrolyzable tannins & Resveratrol \\
Stilbenes & Secoisolariciresinol, matairesinol, \\
Lignans & lariciresinol, pinoresinol \\
& \\
Flavonoid compounds & Kaempferol; quercitin; myricetin \\
Flavonols & Apigenin; luteolin \\
Flavones & Naringenin; hesperetin \\
Flavanones & Catechins; gallocatechins \\
Flavanols & Pelargonidin; cyanidin; malvidin \\
Anthocyanidins & Trimeric procyanidin, \\
Condensed tannins or & prodelphinidins \\
proanthocyanidins & Daidzein; genistein; glycitein \\
Isoflavones &
\end{tabular}

collectively known as chlorogenic acids (CGA) (Clifford, 1985a). Other phenolic compounds, such as tannins, lignans and anthocyanins are also present in coffee seeds although in minor amounts. CGA, which are present in high concentrations in green coffee seeds (up to $14 \%$ ), have a marked influence in determining coffee quality and play an important role in the formation of coffee flavor (Carelli et al., 1974; Clifford and Wight, 1976; Trugo and Macrae, 1984a, Variyar et al., 2003, Farah, 2006a). Moreover, these compounds have several beneficial health properties largely explained by their potent antioxidant activity. In addition, they have exhibited hypoglycemic, antiviral, hepatoprotective and antispasmodic activities (Basnet et al., 1996; Trute et al., 1997; Trugo, 2001; Grace et al., 1998; Natella et al., 2002; Pereira et al., 2003, Moreira et al., 2005). Their 1,5- $\gamma$-quinolactones have also been studied not only for their potential hypoglycemic effects but for their action in the brain function, more specifically, at the mu opioid and adenosine receptors (Farah et al., 2005a).

This review focuses on the chemical characteristics, biosynthesis, and composition of CGA and related compounds in coffee, with emphasis on the influence of genetic, physiological and environmental factors, as well as processing, on the CGA composition of green coffee beans. The impact of CGA composition on coffee cup quality is also discussed.

\section{Phenolic composition of coffee fruit}

Coffee pulp and skin: In recent years, the number of studies on the chemical composition of coffee skin and pulp has been increasing due to their potential use in animal feeding, especially in coffee producer countries, where the disposal of wastes represents an important pollution problem. (Ulloa Rojas et al., 2002; Barcelos et al., 2002). Tannins, which are the main phenolic compounds in these parts of the coffee fruit, have received a special attention because they are considered as anti-nutrients for ruminants (Barcelos et al., 2001; Barcelos, 2002; Ulloa Rojas et al., $2002,2003)$. Soluble tannins may account for $0.8 \%-2.8 \%$ of C. arabica and C. canephora skin and pulp, with higher contents observed in $C$. canephora, and with prodelphinidins exceeding procyanidins (Clifford and Ramirez-Martinez, 1991a; Barcelos et al., 2001; Ulloa Rojas et al., 2003). Small amounts of insoluble condensed tannins may be also found in the pulp (Clifford and Ramirez-Martinez, 1991a). Soaking the pulp in water, treatment with alkali solutions, ensilation with molasses, and inoculation with selected microorganisms 
may destroy or reduce the content of tannins (Ulloa Rojas et al., 2002; 2003). Storage of dehydrated arabica coffee skin and pulp also produced a linear decrease in tannins content ( 39\%/year) (Barcelos et al., 2001).

Smaller amounts of the main groups of CGA found in coffee beans (caffeoylquinic acids, feruloylquinic acids and dicaffeoylquinic acids were identified in the pulp (Clifford and Ramirez-Martinez, 1991b). Griffin and Stonier (1975, cited by Clifford, 1985) have reported that coffee pulp contains CGA-protein complexes that are able to inhibit the enzyme indole acetic acid oxidase. Anthocyanins are commonly found in skin material of red fruit cultivars (Mazza and Miniati, 1993).
Coffee beans: CGA have been studied for more than a century as the main components of the phenolic fraction of green coffee beans (Clifford, 1979; Trugo, 1984). CGA include different groups of compounds and related isomers formed by esterification of one molecule of quinic acid and one to three molecules of a specific trans-hydroxycinnamic acid (figure 1). Using the preferred IUPAC numbering system (Clifford, 1985a; 2000), quinic acid (1L$1(\mathrm{OH}), 3,4 / 5$-tetrahydroxy-cyclohexane carboxylic acid) has axial hydroxyl groups on carbons 1 and 3, and equatorial hydroxyls on carbons 4 and 5. Esters of this acid are usually formed on carbon 5, but also on carbons 3 and 4, and less commonly on carbon 1 . Hydroxy-cinnamic acids are trans-<smiles>O=C(O)C1(O)CC(O)C(O)C(O)C1</smiles><smiles>[R]c1cc(/C=C/C(=O)O)ccc1O</smiles>

$$
\begin{array}{ll}
\mathrm{R}_{1}=\mathrm{OH} & \mathrm{CA} \\
\mathrm{R}_{1}=\mathrm{OCH}_{3} & \mathrm{FA} \\
\mathrm{R}_{1}=\mathrm{H} & p \mathrm{CoA}
\end{array}
$$

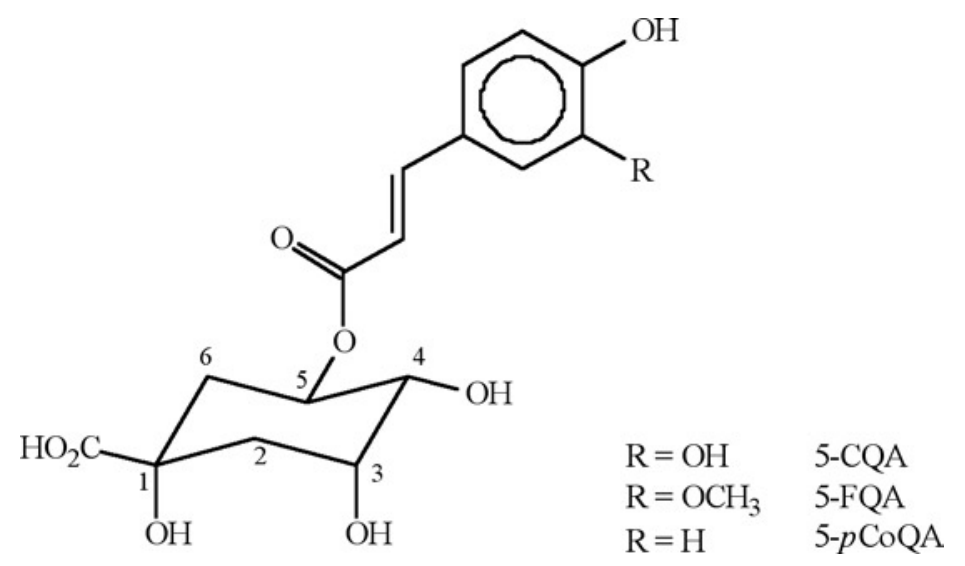

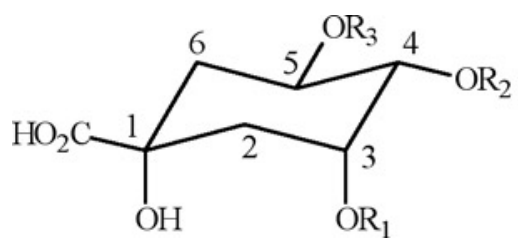

$\mathrm{R}_{1}=\mathrm{CA}, \mathrm{R}_{2}=\mathrm{CA}, \mathrm{R}_{3}=\mathrm{H}$

$\mathrm{R}_{1}=\mathrm{CA}, \mathrm{R}_{2}=\mathrm{H}, \mathrm{R}_{3}=\mathrm{CA}$

3,4-diCQA

$\mathrm{R}_{1}=\mathrm{H}, \mathrm{R}_{2}=\mathrm{CA}, \mathrm{R}_{3}=\mathrm{CA}$

$\mathrm{R}_{1}=\mathrm{FA}, \mathrm{R}_{2}=\mathrm{CA}, \mathrm{R}_{3}=\mathrm{H}$

$\mathrm{R}_{1}=\mathrm{CA}, \mathrm{R}_{2}=\mathrm{FA}, \mathrm{R}_{3}=\mathrm{H}$

$\mathrm{R}_{1}=\mathrm{FA}, \mathrm{R}_{2}=\mathrm{H}, \mathrm{R}_{3}=\mathrm{CA}$

$\mathrm{R}_{1}=\mathrm{CA}, \mathrm{R}_{2}=\mathrm{H}, \mathrm{R}_{3}=\mathrm{FA}$

$\mathrm{R}_{1}=\mathrm{H}, \mathrm{R}_{2}=\mathrm{FA}, \mathrm{R}_{3}=\mathrm{CA}$

$\mathrm{R}_{1}=\mathrm{H}, \mathrm{R}_{2}=\mathrm{CA}, \mathrm{R}_{3}=\mathrm{FA}$
3,5-diCQA

4,5-diCQA

3F,4CQA
3C,4FQA
3F,5CQA
3C,5FQA
4F,5CQA
4C,5FQA

Figure 1. Chlorogenic acids and related compounds according to chemical characteristics. (A) Basic compounds; (B) monoesters of quinic acid with hydroxy-cinnamic acids (example of 5-isomers); (C) di-esters of quinic acid with caffeic acid, and (D) mixed esters 
phenyl-3-propenoic acids with different substitutions in the aromatic ring; the most common in coffee is caffeic acid (3,4-dihydroxy-cinnamic acid) followed by ferulic acid (3metoxy, 4-hydroxy-cinnamic acid) and $p$-coumaric acid (4hydroxy-cinnamic acid) (Clifford, 2003).

The main groups of CGA found in green coffee beans are presented in figure 1, according to their chemical identity, number and position of acyl residues. These groups of compounds include: caffeoylquinic acids (CQA), with 3 isomers (3-, 4- and 5-CQA); dicaffeoylquinic acids (diCQA), with 3 isomers (3,4-diCQA; 3,5-diCQA; 4,5-diCQA); feruloylquinic acids (FQA), with 3 isomers (3-, 4- and 5FQA); $p$-coumaroylquinic acids ( $p$ CoQA), with 3 isomers (3-, 4- and 5- $p$ CoQA), and six mixed diesters of caffeoylferuloyl-quinic acids (CFAQ) (Clifford, 2003).

Despite the large distribution of some CGA in the plant kingdom, green coffee is known as one of the main food sources of CGA, with contents being equaled or exceeded only by the green leaves of Illex paraguayensis (Maté) (Clifford and Ramirez-Martinez, 1990; Mazzafera, 1997; Clifford, 1997; Clifford, 1999). Total CGA content of green coffee beans may vary according to genetics - species and cultivar, degree of maturation and, less importantly, agricultural practices, climate and soil (Clifford, 1985, Guerrero et al., 2001; Camacho-Cristóbal et al., 2002, Farah et al., 2005b). The diversity of methodology employed in the analysis of CGA is another important factor in establishing levels, since there may be a certain discrepancy between results obtained by high resolution chromatographic methods and those obtained by less sophisticated methods.

In general, the values described in the literature for total CGA in regular green coffee beans, on dry matter basis (dm), may vary from 4 to $8.4 \%$ for Coffea arabica, and from 7 to $14.4 \%$ for Coffea canephora, with some hybrids presenting intermediate levels (Ferreira et al., 1971; Roffi et al., 1971; Chassevent et al., 1973; Clifford and Wight, 1976; Rees and Theaker, 1977; Van der Stegen and Van Duijn, 1980; Trugo and Macrae, 1984b; Clifford, 1985; Tono et al., 1989; Ky et al., 2001; Maria et al., 1994; Farah et al., 2005a, 2005b). A low CGA content $(1.2 \%, \mathrm{dm})$ was found in beans of Coffea pseudozanguebariae, a caffeine-free species native of East Africa (Clifford and Ramirez-Martinez, 1991a). Such low content has been also observed in some other low-caffeine or caffeine-free species from Africa (Clifford, 1985).

In addition to the major chlorogenic acids cited above, other minor compounds of the CGA family have been reported. Recently, trace amounts of diferuloylquinic acids, dimethoxycinamoylquinic acids, caffeoyl-dimethoxycinamoylquinic acids and feruloyl-dimethoxycinamoylquinic acids were identified in Robusta coffee (Clifford et al., 2006). CGA-caffeine complexes in coffee seeds have been described (Clifford, 2000). The same CGA-protein complexes identified in coffee pulp were also identified in immature coffee seeds (Griffin and Stonier, 1975, cited by Clifford, 1985). Small amounts of caffeic, ferulic, $p$-coumaric and quinic acids may be found in green coffee beans in their free form (Clifford 1985, Clifford, 1987). The occurrence of cinnamoyl conjugates such as caffeoyl-tryptophan (Schrader et al., 1996; Murata et al., 1995), p-coumaroyl-tryptophan (Murata et al., 1995, Clifford, 1997), and caffeoyl-tyrosine (Correia et al., 1995, Clifford, 1997) has also been reported, but quantitative data is not available (Clifford, 2000). Although CGA lactones are mostly produced during roasting of the beans (see below), the presence of trace amounts of some lactones, attributed to primary processing (for example, drying of the beans) has been reported in unroasted coffee beans (Schrader et al., 1996; Farah et al., 2005a).

Table 2 presents the contents of the three main groups of CGA in samples of green coffee beans, obtained by chromatographic analytical methods. Considering the nine main isomers of CGA: 5-CQA; 4-CQA and 3-CQA; 3,5-diCQA, 4,5-diCQA and 3,4-diCQA, 5-FQA, 4-FQA and 3-FQA, in order of abundance in green coffee beans, 5-CQA alone is responsible for about 56-62 \% of total CGA. Considering that 4-isomers usually equal or slightly exceed 3-isomers, 3-CQA and 4-CQA account for up to $10 \%$ each of total CGA. DiCQA isomers account for about $15-20 \%$ of total CGA in green coffee beans and FQA isomers, for $5-13 \%$ of total CGA. $p$-CoQA isomers, CFQA isomers and the newly identified diferuloylquinic acids and dimetoxycinnamoylquinic acid derivatives account together for the remaining percentage (Clifford and Wight, 1976; Trugo and Macrae, 1984ab; Clifford, 1985; Shrader et al., 1996; Clifford, 2003; Farah et al., 2001, 2005a, 2005b; Farah, 2004; Clifford et al., 2006).

Not only total CGA content, but the CGA composition of coffee beans also varies considerably during fruit maturation. Considering variations between species and cultivars (Ohiokpehai et al., 1982), a sigmoidal increase in total CQA, mostly in parallel with the total dry matter gain, is initially observed with maturation (Clifford and Kasi, 1987). The ratio CQA/diCQA appears to increase with maturation until ripeness of the fruit (Menezes, 1994a; Clifford and Kasi, 1987), probably due to hydrolysis of diCQA into mono- 
esters. At a certain stage before ripeness, CQA content starts to drop, according to Montavón et al. (2003), due to oxidation. From this point on, an inverse association between the levels of CQA and coffee fruits maturation is observed (Menezes, 1994b). Recently, Farah et al (2005b) reported a reduction not only in CQA levels, but also in FQA and diCQA levels, at this last stage of maturation. The authors reported a total of $8.7 \%$ of CGA (dm) for immature C. arabica seeds (from dark green fruits), while seeds of over-ripened fruits presented levels as low as $1.3 \%$. Montavón et al (2003) suggested that unripe seeds are more sensitive towards oxidation than ripe seeds and that the lower sensitivity of ripe seeds occurs because the defense mechanisms against oxidative stress become more efficient during maturation. Alternatively, according to the same authors, mature beans may contain lower polyphenol oxidase and peroxidase activities than immature beans. This hypothesis is in agreement with the reduction in polyphenol oxidase activity observed at later stages of maturation
(Arcila-Pulgarin and Valência-Aristizabal, 1975; Mazzafera and Robinson, 2000).

Despite the discrepancy caused by the use of different analytical methods, the large variation in CGA content and isomers distribution, along with qualitative differences (presence and absence of some isomers) in green coffee beans make the CGA content a potential criterion on coffee genotype selection (Clifford et al., 1989; Correia et al., 1995; Guerrero at al, 2001; Ky et al., 2001). A correlation between the pattern of minor CGA-like compounds with the geographical origin of the beans has been observed and attributed to genetic factors rather than to agricultural practices (Clifford and Jarvis, 1988; Correia et al., 1995). However, as stated before, small variations in CGA content of coffee beans from ripe fruits may be observed due to weather and agricultural practices. Severe weather conditions such as cold, high visible light and water stress conditions tend to increase the contents of phenolic compounds not only in the

Table 2. Chlorogenic acids content in green coffee beans, expressed in $\mathrm{g}^{\mathrm{a}}{ }^{\mathrm{a}}$, dry matter basis.

\begin{tabular}{|c|c|c|c|c|c|}
\hline Samples & CQA & FQA & diCQA & Total CGA & References \\
\hline C. arabica & 5.76 & 0.25 & 0.87 & 6.88 & Trugo \& Macrae, 1984 \\
\hline $\begin{array}{l}\text { C. arabica var } \\
\text { Caturra }\end{array}$ & 4.63 & 0.33 & 0.66 & 5.62 & Clifford \& Ramirez-Martinez ,1991 \\
\hline C. arabica var. Bourbon & 4.77 & 0.34 & 0.56 & 5.67 & Clifford \& Ramirez-Martinez ,1991 \\
\hline Wild C. arabica (average) & 3.26 & 0.19 & 0.60 & 4.10 & Ky et al., 2001 \\
\hline C. $\operatorname{arabica}$ (Angola) & 4.30 & 0.57 & 1.23 & 6.10 & Correia et al., 1995 \\
\hline C. $\operatorname{arabica}$ (Angola) & 4.84 & 0.28 & 0.53 & 5.65 & Correia et al., 1995 \\
\hline C. $\operatorname{arabica}$ (Angola) & 5.67 & 0.79 & 1.39 & 7.85 & Correia et al., 1995 \\
\hline C. arabica var Boubon (Brazil) & 4.2 & 0.28 & 0.77 & 5.25 & Farah et al., 2005a \\
\hline C. arabica $\mathrm{cv}$. Longberry (Ethiopia) & 4.6 & 0.29 & 0.84 & 5.73 & Farah et al., 2005a \\
\hline C. canephora cv Robusta & 6.82 & 0.60 & 1.37 & 8.80 & Trugo \& Macrae ,1984 \\
\hline C. canephora cv Robusta & 5.33 & 0.79 & 1.05 & 7.17 & Clifford \& Ramirez-Martinez, 1991 \\
\hline C. canephora cv Robusta (Angola) & 3.43 & 0.54 & 1.20 & 6.08 & Correia et al., 1995 \\
\hline C. canephora cv Robusta (Angola) & 4.97 & 0.75 & 1.46 & 7.18 & Correia et al., 1995 \\
\hline C. canephora cv. Conillon (Brasil) & 7.42 & 0.95 & 1.09 & 9.47 & Farah et al., 2001 \\
\hline Wild C. canephora (average) & 7.66 & 1.43 & 2.31 & 11.3 & Ky et al., 2001 \\
\hline C. canephora var. Robusta (Uganda) & 5.77 & 0.47 & 1.34 & 7.58 & Farah et al., 2005a \\
\hline Timor hybrid (C.arabica x C. canephora) & 4.71 & 0.33 & 0.58 & 5.62 & Clifford and Ramirez-Martinez, 1991 \\
\hline Catimor (Timor hybrid x C. arabica) & 5.51 & 0.35 & 0.45 & 6.31 & Clifford and Ramirez-Martinez, 1991 \\
\hline C. liberica cv. Dewevrei & 5.39 & 0.48 & 1.1 & 6.97 & Ky et al., 1977 \\
\hline
\end{tabular}

CQA- caffeoyilquinic acid; FQA - feruloyiquinic acid; diCQA dicaffeoyilquinic acid. Total CGA - total chlorogenic acids. ${ }^{\text {a }}$ Units may have been changed for consistency ${ }^{a}$ 
coffee plant and seed but also in other plants (Douglas, 1996; Grace et al., 1998; Materska and Perucka, 2005; Pennycooke et al., 2005). The use of nitrogen-rich fertilizers (Malta et al., 2003) and situations of boron deficiency (Camacho-Cristobal, et al., 2002) have also shown to increase the content of total CGA in coffee seeds and other plants.

Small amounts of phenolic compounds different from CGA and related compounds have been identified in green coffee beans. The presence of about $1 \%$ of phenolic glycosides has been suggested (Clifford, 1985). Anthocyanidins such as cyanidins, pelargonidins and one peonidin were identified in arabica coffee seeds as a residue of red skin fruits. (Mazza and Miniati, 1993). Lignans such as secoisolariciresinol, lariciresinol, matairesinol and pinoresinol, in order of abundance, are also present in coffee (Milder et al., 2005). Some free volatile phenols have been identified (Moreira et al., 2000). Tannins have not been identified in wet processed coffee seeds (Clifford and Ramirez-Martinez, 1991a). However, it is possible that dry processed beans contain a small amount of tannins as a residue of the coffee pulp.

\section{Biosynthesis of chlorogenic acids and relevance for the plant physiology}

CGA are products of the phenylpropanoid pathway, one branch of the phenolic metabolism in higher plants that is induced in response to environmental stress conditions such as infection by microbial pathogens, mechanical wounding, and excessive UV or high visible light levels (Herrmann, 1995; Haard and Chism, 1996). Plant phenolic acids are synthesized from phenylalanine and tyrosine via the shikimic acid pathway, which converts simple carbohydrate precursors, derived from glycolysis and the pentose phosphate shunt (phospho-enol-pyruvate and D-erythrose4-phosphate), into aromatic amino acids (figure 2). The parent trans-cinnamic acid is formed from L-phenylalanine by the action of phenylalanine ammonia-lyase, a key enzyme in the biosynthesis of phenolic compounds that is activated in response to different stress conditions. Quinic acid is synthesized from 3-dehydroquinate, an intermediate metabolite of the shikimic acid pathway. Hydroxy-cinnamic acids ( $p$-coumaric, caffeic, ferulic and sinapic) may be synthesized from cinnamic acid by hydroxylation or alternatively from tyrosine by the action of tyrosine aminolyase (figure 2).

The final steps of biosynthesis of the 5-monoacyl CGA (5-CQA, 5-FQA and 5-p-CoQA) have been studied in several plants as well as coffee and appear to include binding of trans-cinnamic acid to coenzyme A (CoA) by a CoA lyase, followed by transfer to quinic acid by a cinnamoyl transferase (Gross, 1981). The origin of the CGA with acyl groups in positions 3- and 4- is unclear, although the possibility of acyl migration has been considered (Gross, 1981). Once formed, phenolic acids and CGA can be substrate of enzymes such as polyphenol oxidase (Mazzafera and Robinson, 2000) and

\section{Phosphoenol pyruvate + Erythrose 4-phosphate \\ $\downarrow$ \\ 5-Dehydroquinic acid $\rightarrow$ Quinic acid $\downarrow$}

5-Dehydroshikimic acid

$\downarrow$

Shikimic acid

$\downarrow$

Shikimate 5-phosphate

3-Enolpyruvoylshikimate 5-phosphate

$\downarrow$

Chorismate

$\downarrow$

Arogenic acid

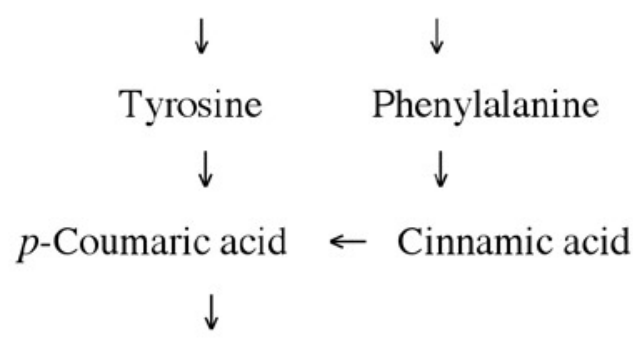

Caffeic acid

$\downarrow$

Ferulic acid<smiles>[AlH]</smiles>

Sinapic acid

Figure 2. Biosynthesis of cinnamic/hydroxycinnamic acids and quinic acid via the shikimic acid pathway 
peroxidase (Takahama, 2004), leading to polymerization products such as insoluble brown pigments and lignin that contribute to the plant defense mechanisms and to the synthesis of plant cell wall constituents.

Besides the recognition that CGA play an important role in plant stress adaptation, there are indications that these compounds may have specific physiological functions in the coffee plant, consistent with the relatively high levels of CGA usually found in coffee seeds (Clifford, 1987; Leloup et al., 1995). CGA synthesis in the coffee plant may contribute to the control of seed germination and cell growth, through regulation of the levels of indolacetic acid - a plant growth hormone of physiological significance during the formation and germination of the beans - and possibly also through other still unknown mechanisms (Griffin and Stonier, 1975, cited by Clifford, 1985; Clifford 1985).

CGA are found in the surface of coffee seeds, in association with the cuticular wax, and in the cytoplasm adjacent to the cell walls of the endosperm parenchyma (Clifford, 1987), but there seem to be no reports whether the distribution of CGA differ in these two locations. According to Horman and Viani (1971, cited by Clifford, 1985) and Zeller and Saleeb (1997), part of the cell wall CGA may be associated with caffeine, as a 1:1 or 2:1 molar complex. Although CGA are mostly found in the coffee seeds, they have also been found in the leaves and in the coffee pulp (Clifford and Ramirez- Martinez, 1991a).

\section{Changes in chlorogenic acids composition of coffee beans during processing}

Roasting: In addition to their relevance for plant physiology and for a potential use in the pharmacology field, CGA take part in the generation of color, flavor and aroma of coffee during roasting (Trugo and Macrae, 1984a; Moreira et al., 2000; Montavón et al., 2003). Due to their thermal instability, CGA may be almost completely degraded into phenol derivatives when submitted to intense roasting conditions. During roasting, part of CGA is isomerized, part is transformed into quinolactones due to dehydration and formation of an intramolecular bond (figure 3), and part is hydrolyzed and degraded into low molecular weight compounds (Trugo, 1984, Trugo and Macrae, 1984a; Leloup et al., 1995; Clifford, 2000; Farah et al., 2005a). CGA also participate in the formation of polymeric material like melanoidins (Menezes, 1994a, Steinhart and Luger, 1997). Drastic roasting conditions may produce losses of up to $95 \%$ of CGA (Trugo, 1984), with $8-10 \%$ being lost for every $1 \%$ loss of dry matter (Clifford, 1997, 1999, 2000). Total CGA content in commercial roasted coffee ranges from about 0.5 to $7 \%$ (table 3 ), depending on the type of processing, roasting degree, blend and analytical conditions. CGA contents in light to medium roasted coffees still stand out when compared to most food sources of CGA (Farah et al., 2001; Clifford, 2002). While coffee abstainers may typically
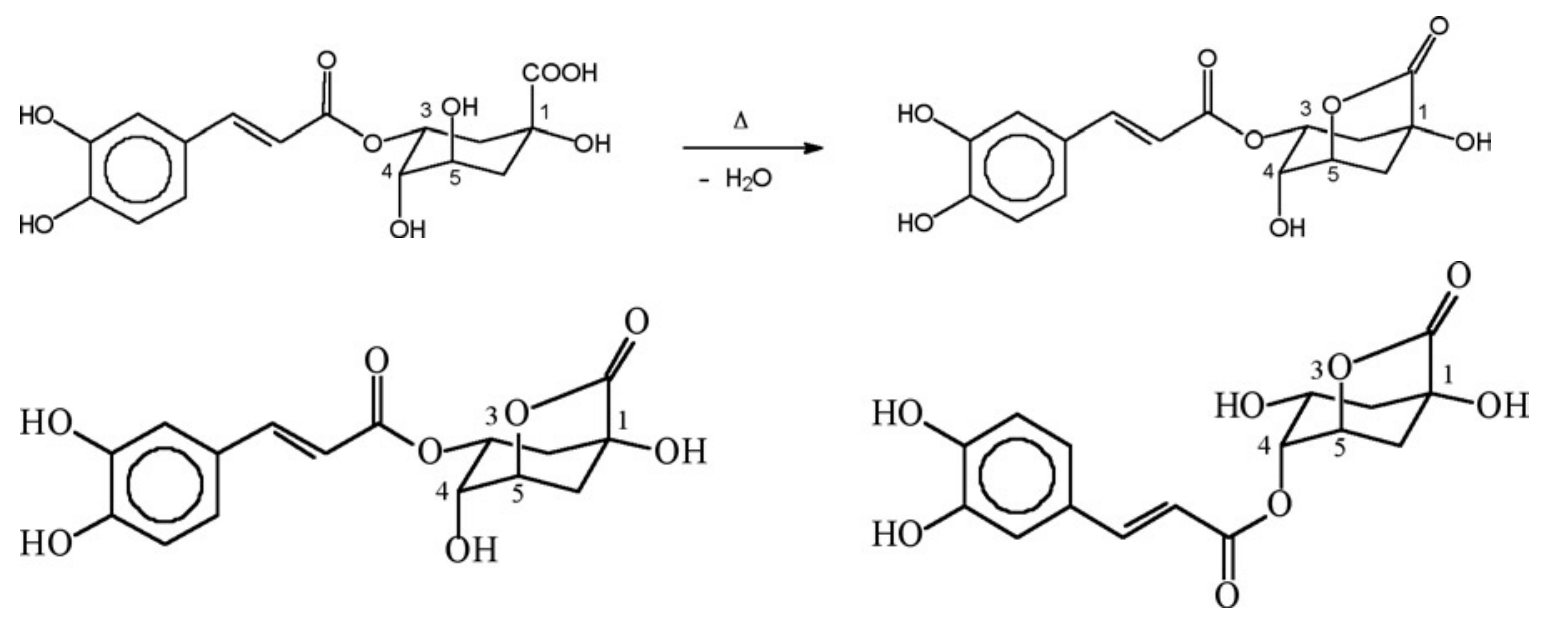

Figure 3. Formation of a 1,5- $\gamma$-quinolactone from chlorogenic acid during roasting (A), and the two major chlorogenic acid lactones in roasted coffee: 3 -caffeoylquinic-1,5- $\gamma$-lactone (left) and 4-caffeoylquinic-1,5- $\gamma$-lactone (right) (B) Although under IUPAC rules the numbering system for the lactones is different from that for the acids, in order to avoid confusion, most reports in the literature (including the present work) have been using for lactones the same numbering of the carbons as for the acid precursors. 
ingest less than $100 \mathrm{mg}$ of CGA/day, modest and heavy coffee drinkers intake may range from 0.1 to $2 \mathrm{~g}$ (Clifford, 1997, 2000; Del Castillo et al., 2002).

In relation to changes in CGA individual subgroups and isomers during roasting, at the beginning of the roasting process, isomerization of CGA occurs. The levels of the substitutes of the 5-position of the quinic acid decrease substantially while those of the substitutes in the 3- and 4- positions increase in some cases to almost double their original levels. (Trugo and Macrae, 1984; Leloup et al., 1995, Farah et al., 2005a). According to Leloup et al (1995), at this roasting stage, diCQA may be partially hydrolysed into monoesters and cafeic acid, which may be again hydrolysed, decarboxylated and degraded to a range of simple phenols. Levels of volatile phenols increase along the process (Moreira et al., 2000). Chlorogenic acid lactones formation occurs after 6 to $7 \%$ of weight loss (Hucke and Maier, 1985; Farah et al., 2005a). About 7\% of CGA in regular Arabica coffee and 5.5\% in Robusta coffee seem to be transformed into 1,5- $\gamma$-quinolactones during the roasting process (figure 3). Average lactones levels of 210 and $100 \mathrm{mg} \%(\mathrm{dm})$ were reported for commercial regular ground coffee (Shrader et al., 1996) (table 3).

Table 3. Chlorogenic acids and quinolactones in ground roasted and instant coffee, expressed in g\%, dry matter basis.

\begin{tabular}{|c|c|c|c|c|c|c|c|c|c|c|}
\hline Coffee Samples & CQA & FQA & $\begin{array}{c}\mathrm{Di} \\
\mathrm{CQA} \\
\end{array}$ & $\begin{array}{l}\text { Total } \\
\text { CGA }\end{array}$ & CQL & FQL & $\begin{array}{c}\mathrm{Di} \\
\mathrm{CQL} \\
\end{array}$ & CoQL & Total CGL & References \\
\hline \multicolumn{11}{|l|}{ Ground Roasted Coffee } \\
\hline \multirow[t]{5}{*}{ Commercial } & 2.70 & & & & 0.26 & & & & & Bennat et al.,1994 \\
\hline & 2.64 & & & & 0.34 & & & & & \\
\hline & 1.94 & & & & 0.23 & & & & & \\
\hline & 0.81 & & & & 0.17 & & & & & \\
\hline & 1.00 & & & & 0.16 & & & & & \\
\hline $\begin{array}{l}\text { Commercial } \\
\text { (average) }\end{array}$ & 2.26 & 0.21 & 0.19 & 2.66 & 0.31 & & & & & Shrader et al.,1996 \\
\hline \multirow[t]{4}{*}{ Commercial } & 1.25 & 0.22 & 0.19 & 1.66 & & & & & & Monteiro \& Trugo, 2005 \\
\hline & 1.29 & 0.19 & 0.24 & 1.72 & & & & & & \\
\hline & 0.85 & 0.12 & 0.09 & 1.06 & & & & & & \\
\hline & 0.38 & 0.06 & 0.03 & 0.47 & & & & & & \\
\hline $\begin{array}{l}\text { C. arabica }{ }^{\mathrm{b}} \text { Bourbon } \\
\text { (Brazil) }\end{array}$ & 2.15 & 0.17 & 0.14 & 2.46 & 0.36 & 0.04 & 0.01 & 0.01 & 0.41 & Farah et al., 2005a \\
\hline $\begin{array}{l}\text { C.arabica }{ }^{\text {b }} \\
\text { Longberry (Ethiopia) }\end{array}$ & 1.65 & 0.15 & 0.13 & 1.93 & 0.33 & 0.04 & 0.01 & 0.01 & 0.38 & Farah et al., 2005a \\
\hline C. arabica & 3.23 & & & & 0.32 & & & & & Bennat et al., 1994 \\
\hline $\begin{array}{l}\text { C.arabica }{ }^{\mathrm{b}} \\
\text { Decaffeinated } \\
\text { (average) }\end{array}$ & & & & 1.80 & 0.38 & 0.06 & 0.01 & & 0.45 & Farah et al., 2006b \\
\hline $\begin{array}{l}\text { C.canephora }^{\text {b }} \\
\text { cv. Robusta } \\
\text { (Uganda) }\end{array}$ & 2.76 & 0.34 & 0.23 & 3.33 & 0.39 & 0.03 & 0.03 & & 0.45 & Farah et al., 2005a \\
\hline \multicolumn{11}{|l|}{ Instant Coffee } \\
\hline \multirow[t]{2}{*}{ Non-decaffeinated } & 5.28 & 1.16 & 0.53 & 6.97 & & & & & & Trugo \& Macrae, 1984a \\
\hline & 0.63 & 0.06 & 0.03 & 0.72 & & & & & & Nogueira \& Trugo, 2003 \\
\hline \multirow[t]{2}{*}{ Non-decaffeinated } & 2.41 & 0.27 & 0.09 & 2.77 & & & & & & \\
\hline & 1.30 & 0.14 & 0.04 & 1.48 & & & & & & \\
\hline \multirow[t]{2}{*}{ Decaffeinated } & 4.73 & 0.84 & 0.28 & 5.85 & & & & & & Nogueira \& Trugo, 2003 \\
\hline & 3.33 & 0.60 & 0.17 & 4.10 & & & & & & \\
\hline
\end{tabular}

a Units may have been changed for consistency; ${ }^{b}$. Laboratory roasted - light medium roast. 
The 3-caffeoylquinide or 3-caffeoylquinic-1,5-lactone (3-CQL) is the main lactone, with maximum levels of 230 and $254 \mathrm{mg} \%(\mathrm{dm})$, in Arabica and Robusta coffees, respectively (Farah et al., 2005a). The second major lactone is 4-caffeoylquinic-1,5-lactone (4-CQL), with average contents of 116 and $139 \mathrm{mg} \%$, for Arabica and Robusta coffees, respectively (Farah et al., 2005a). 3-CQL and 4-CQL (figure 3 ) are expected to be the major 1,5- $\gamma$-quinolactones, since caffeoylquinic acids are the main CGA and only those CGA isomers that lack a substitute in the 5-position are able to form a 1,5- $\gamma$-quinolactone. Lactone formation of 3-CQA is favored relative to 4-CQA because of steric hindrance of the ester group in axial position of the equatorial conformer (Farah et al., 2005a). Lactones from FQA, diCQA and $p$-CoQA, in order of relevance (table 3 ) and other minor quinides, have also been identified in roasted coffee (Scholts and Maier, 1990; Scholz-Bottcher et al., 1991; Flores-Parra et al., 1989; Farah et al., 2005a).

The content of total CGA lactones increases until about $14 \%$ weight loss, i.e., light medium roast, reaching average levels of 398 and $424 \mathrm{mg} \%$ (dm) for Arabica and Robusta coffees, respectively, and decreasing gradually thereafter (Farah et al., 2005a, Bennat et al., 1994).

The extraction of chlorogenic acids into the beverage depends on the grind of coffee, the proportion of coffee to water, the brewing method, the water temperature and length of time coffee is in contact with water, but domestic brewing substantially extracts CGA $(80-100 \%)$ and CGL from roasted coffee (Clifford, 1997; 2000). Higher temperatures under $100^{\circ} \mathrm{C}$ result in greater extraction of CGA (Trugo and Macrae, 1984a; Clifford, 1987). Extraction rate increases over the first 10 min commonly employed in domestic brewing. The highest extraction rate of CGA usually occurs in the first 2 min at $93^{\circ} \mathrm{C}$, increasing less rapidly thereafter (Merrit and Proctor, 1959, Clifford, 1987). Domestic extraction will result in $70-200 \mathrm{mg}$ of CGA per $200 \mathrm{ml}$ cup, in the case of Arabica coffee and 70-350 mg of CGA per $200 \mathrm{ml}$ cup in Robusta coffee (Clifford, 1997). Keeping coffee brews at an elevated temperature reduces the contents of both CQA and CQL in the brew (Bennat et al., 1994; Schrader et al., 1996).

Decaffeination: Moreira et al (2005) measured the contents of CGA in ground and instant, light and dark roasted, regular and decaffeinated Brazilian commercial coffee samples, and observed lower CGA contents in all decaffeinated samples, compared to non-decaffeinated ones. An average loss of $10 \%$ was observed by Farah et al (2006b) in CGA contents of de- caffeinated and roasted Arabica coffee samples, in comparison with non-decaffeinated samples roasted in the same conditions. On the other hand, a 7\% average increase in lactones content was observed in the same samples (table 3).

Instant coffee processing: A large variation in the contents of total CGA was observed upon analysis of thirteen commercial instant coffee samples from England (3.6-10.7 $\%$, dm -Trugo and Macrae, 1984b) and nine from Brazil (0.6-5.9 \%, dm - Nogueira and Trugo, 2003) (table 3). In the respective samples, 5-CQA alone accounted for about $30 \%$ of total CGA; CQA accounted for $70 \%$; FQA for $20 \%$ and diCQA for $10 \%$. The large difference in CGA levels was attributed to the use of different blends and roasting degrees, whereas the low percentage of diCQA was attributed to loss during processing (Trugo and Macrae, 1984b, Nogueira and Trugo, 2003). Bennat et al (1994) also performed analysis of CQA and lactones in instant coffee and attributed the low content of lactones to hydrolysis during processing.

\section{Special types of processing}

Steam-treated coffee: Coffee may be steam-treated prior to roasting as a means to make coffee "less irritable" to the stomach, and therefore acceptable to persons with stomach problems (Steinhart and Luger, 1997). Degradation of CGA during steaming of green beans has been reported as a consequence of increased water uptake (Maier, 1994).

Monsooned coffee: This is a speciality coffee of India, which undergoes a natural process of curing dry raw Arabica and Robusta coffee beans by exposing them to moist monsoon winds prevailing in the costal regions of Mangalore and Tellichery. Variyar et al (2003) observed a substantial decrease in CGA levels of this type of speciality coffee, accompanied by an increase in the levels of free caffeic acid, which was attributed to hydrolysis of CGA during the process. Balyaya and Clifford (1995) also observed higher levels of free caffeic acid in monsooned coffee beans.

Irradiation: This treatment has been applied to green beans as a method to control microbiological contamination and insect infestation. While Deshpande and Aguilar (1975) did not observe differences in CGA and caffeic acid contents of Arabica and Robusta beans treated with gamma irradiation, Variyar et al. (2003) observed a substantial decrease in CGA contents of irradiated beans in comparison with 
non-irradiated ones. The decrease in CGA level was not accompanied by an increase in caffeic acid levels, which was attributed to degradation of CGA, and not to hydrolysis, as it was the case with monsooned beans. Gamma-irradiation has been reported to reduce the contents of cinnamic acids in food products (Clifford, 2000).

\section{Chlorogenic acids composition and coffee quality}

CGA are known to be important determinants of coffee flavor. They contribute to the final acidity (Trugo and Macrae, 1984) and confer astringency (Carelli et al., 1974; Clifford and Wight, 1976; Variyar et al., 2003) and bitterness (Trugo, 1984) to the beverage. As a result of Maillard and Strecker's reactions, bitterness increases during roasting due to release of caffeic acid and formation of lactones and other phenol derivatives responsible for flavor and aroma (Ginz and Enhelhardt, 1995; Maria et al., 1994, Variyar et al., 2003).

The relationship of CGA with coffee cup quality is still unclear and somehow controversial. Okiokpehai (1982) reported that the addition of diCQA conferred a disagreeable flavor to coffee beverage, which disappeared on subsequent addition of CQA. However, according to Silva (1999), total CGA levels present and inverse association with coffee quality, with higher CGA content being observed in lower quality samples. Considering that CQA accounts for at least $60 \%$ of CGA contents in roasted coffee, higher levels of CQA would be more likely to be associated with low cup quality. Farah et al. (2006a) also observed a strong association between the levels of CQA and FQA and low cup quality. The decrease in quality was accompanied by an increase in color intensity of raw beans that was attributed indirectly to the presence of reactive orthoquinones formed by the action of the enzyme polyphenol oxidase over these compounds. Therefore, products of CGA oxidation may be associated with cup quality decrease. This data, as well as the data obtained by Silva (1999), are in agreement with reports according to which orthoquinones are responsible for the inhibition of the activity of polyphenol oxidase (Mazzafera and Robinson, 2000). Coffee cup quality is directly related to polyphenol oxidase activity and 5-CQA levels in seeds from mature coffee fruits seem to be inversely associated with polyphenol oxidase activity in coffee beans (Amorin and Silva, 1968, Carvalho et al., 1994; Mazzafera, 1999; Silva, 1999). Moreover, the fact that Amorim et al. (1975) related oxidation products of phenolic compounds as a possible cause for Rio-off-flavor (a negative phenolic note responsible for loss on cup quality) would strengthen the hypothesis of the association between high levels of CQA and FQA with low cup quality.

Amorin (1972) observed that 5-CQA levels above usual levels for a determined species contributed to a decrease in quality. Taking into account the well-known importance of CGA for flavor and aroma formation, there appears to be a limiting high CGA level over which cup quality decreases. Lower CGA levels also appear to explain the superiority of $C$. arabica in beverage quality when compared with $C$. canephora. The large difference in CGA contents of these two species was considered one of the factors responsible for flavor differences between the two species (Trugo and Macrae, 1984b; Ky et al., 2001; Bertrand et al., 2003).

The presence of defective coffee beans is also relevant in establishing coffee quality. The CGA content of most defective beans, excluding physical defects (bored, broken, etc.) and defects of extraneous matter (husks, twigs, stones, etc.), appears to vary according to the degree of maturation of the fruit that generates the respective defect (Farah et al., 2005b). The main defects occur due to strip-picking of immature and overripe fruits along with ripe (cherry) fruits. The five most common defects in coffee that may considerably affect cup quality are immature beans (originated from immature fruits), immature-black beans (immature beans with oxidized skin), black beans (from over-ripened fruits) and sour beans (from fruits fermented on the ground or due to improper processing conditions). Comparing immature and immature-black beans with good quality beans, Mazzafera (1999) observed that the contents of total phenolic substances and 5-CQA were higher in immature and immature-black defective beans. Franca et al. (2004) found lower levels of 5-CQA in black defective beans, compared with good quality and immature defective beans. After analysis of eight CGA isomers in defective coffee beans, Farah et al. (2005b) also observed that immature and immature-black defective beans contained significantly higher levels of all CGA isomers, particularly CQA and FQA, compared to healthy and black defective beans. 5-CQA was the main CGA in all defective beans (50-75\% of total CGA), varying from $5,6 \%(\mathrm{dm})$ in dark green immature beans to $0,6 \%(\mathrm{dm})$ in black defective beans, whereas good quality samples had about $4 \mathrm{~g} \%(\mathrm{dm})$. CGA isomers distribution was similar in good quality beans, immature and immature-black defective beans. However, sour and black defective beans showed an increase of up to $25 \%$ in the isomers 3-CQA, 4-CQA and 4-FQA, in comparison with good quality beans, probably due to the occurrence of isomerization of 5-CQA and 5-FQA, and possibly hydrolysis of diCQA during the 
fermentative process (in the case of sour defects) or aging (in the case of black defects).

\section{Concluding remarks}

The relatively high levels of phenolic acids, particularly of chlorogenic acids and related compounds, in coffee seeds reflect their physiological importance for the coffee plant, as well as their significant contribution to aroma and flavor formation of coffee beverage. Genetic factors such as species and variety, the degree of maturation, and to some extent environmental conditions and agricultural practices, are important determinants of the composition of chlorogenic acids in green coffee beans, and will also affect the composition of the final beverage. Processing, especially roasting, modifies dramatically the phenolic composition of coffee, producing aroma, flavor and color compounds characteristics of coffee beverage.

Although there is considerable published information on total chlorogenic acids content in coffee, less is known on the composition of specific chlorogenic acids isomers and derived components such as lactones. The lack of commercial standards for most of these compounds and the similarity of their chemical structures require highly sensitive chromatographic separation methods coupled to mass spectrometry for proper identification and analysis. More research is needed on these aspects and on the composition of other phenolic compounds in coffee, as well as their impact on cup quality. The effect of different types of processing on coffee phenolic composition also needs to be further explored.

Acknowledgements: The authors thank Daniel Perrone Moreira for assistance with editing of the chemical structures. Original research of the authors, cited in this review, was funded in part by The CBPC - EMBRAPA, CAPES and FAPERJ (Brasil), and by the Institute for Coffee Studies/ Vanderbilt University (EUA).

\section{REFERENCES}

Amorim HV; Silva DM (1968) Relationship between the polyphenol oxidase activity of the coffee beans and the quality of the beverage. Nature 219:381-382.

Amorim HV (1972) Relação entre alguns compostos orgânicos do grão de café verde com a qualidade da bebida. Universidade de São Paulo, Escola Superior de Agricultura "Luiz de Queirós", Piracicaba, SP, Brazil. Doctorate Thesis.

Amorim HV; Teixeira AA; Melo M; Cruz VF; Malavolta E (1975) Chemistry of Brazilian green coffee and quality of beverage. A electrophoresis of proteins in agar-agar gel and its interaction with chlorogenic acid. Turrialba 25:18-24.

Arcila-Pulgarin J; Valencia-Aristizabal G (1975) Relation entre la actividade de la polifenoloxidase (PFO) y las pruebas de catacion como medidas de la calidad de la bebida del café. Cenicafé 26:55-71.

Balyaya KJ; Clifford MN (1995) Chlorogenic acids and caffeine contents of monsooned Indian Arabica and robusta coffees compared with wet and dry processed coffees from the same geographic area. In: Proc $16^{\text {th }}$ Int. Sci. Coll. Coffee. ASIC, Paris, pp.316-325.

Barcelos AF; Paiva PCA; Pérez JRO; Santos VB, Cardoso RM (2001) Fatores antinutricionais da casca e da polpa desidratada de café (Coffea arabica L.) armazenadas em diferentes períodos. Ver. Bras. Zootec. 30:1325-1331.

Barcelos AF; Paiva PCA; Pérez JRO; Santos VB, Cardoso RM (2002) Composição química da casca e polpa desidratada de café (Coffea arabica L.) armazenadas em diferentes períodos. In. Anais do II Simpósio de Pesquisa dos cafés do Brasil. (Vitória, ES- Setembro de 2001),. Consórcio Brasileiro de Pesquisa e Desenvolvimento do café. Embrapa Café, Brasilia, DF. vol II, p.636-639

Basnet P; Matsushige K; Hase K; Kadota S; Namba T (1996) Four di-0-caffeoyl quinic acid derivatives from propolis. Potent Hepatoprotective activity in experimental liver Injury models. Biol. Pharm. Bull. 19:1479-1484.

Bennat C; Engelhardt UH; Kiehne A; Wirries F; Maier HG (1994) HPLC Analysis of chlorogenic acid lactones in roasted coffee. Z. Lebensm. Unters Forsch199:17-21.

Bertrand C; Noirot M; Doulbeau S; Kochko A; Hamon S; Campa C (2003) Chlorogenic acid content swap during fruit maturation in Coffea pseudozanguebarial. Qualitative comparison with leaves Plant Sci. 165:1355-1361

Camacho-Cristóbal JJ, Anzelotti D; González-Fontes A(2002) Changes in phenolic metabolism of tobacco plants during short-term boron deficiency. Plant Physiol. Biochem. 40: 997-1002.

Carelli MLC, Lopes CRO; Monaco LC (1974) Chlorogenic acid content in species of Coffea and selections of arabica. Turrialba 24:398-401.

Carvalho VD; Chalfoun SS; Chagas SJR (1989) Relação entre classificação do café pela bebida e composição fisico química, química e microflora do grão beneficiado. In: Congresso Brasileiro de Pesquisas Cafeeiras, Maringá, p.15.

Carvalho VD; Chagas SJ; Chalfon SM; Botrel N; Juste-Junior ESG (1994) Relação entre a composição química do grão beneficiado e qualidade de bebida do café. Pesq. Agrop. Bras. 29:449-454.

Chassevent F; Gerwig SO; Bouharmont M (1973) Influence eventuelle de diverses fumures sur les teneurs en acides chlorogeniques et en cafeine de grains decafeiers cultives. In: Proc. $6^{\text {th }}$ Int. Sci. Coll. Coffee (Bogotá) ASIC, Paris. p:57-60.

Cheynier V (2005) Polyphenols in foods are more complex than often thought. Am. J. Clin. Nutr. 81(suppl.):223S229S. 
Clifford MN; Wight J (1976) The measurement of feruloylquinic acids and cafeoilquinic acids in coffee beans Development of the technique and its preliminary application to green coffee beans. J. Sci. Food Agric. 27:73-84.

Clifford MN (1979) Chlorogenic acids - their complex nature and routine determination in coffee beans. Food Chem. 4: 63-71.

Clifford MN (1985) Chlorogenic acids. In: Coffee. Vol 1. Chemistry. Clarke RJ; Macrae R (eds) Elsevier Applied Science Publications, London, UK.

Clifford MN (1987) Chemical and physical aspects of green coffee and coffee products. In: Coffee: botany, biochemistry and production of beans and beverage. Clifford MN; Willson KC (eds), pp.457. Chroom Helm, Sydney, Australia.

Clifford MN; Kasi T (1987) The influence of coffee bean maturity on the content of chlorogenic acids, caffeine and trigonelline. Food Chem. 26:59-69.

Clifford MN; Javis T (1988) The chlorogenic acids content of green robusta coffee beans as a possible index of geographic origin. Food Chem. 29:291-298.

Clifford MN; Williams T; Bridson D (1989) Chlorogenic acids and caffeine as possible taxonomic criteria in Coffea and Psilanthus. Phytochemistry 28:829-838.

Clifford MN; Ramirez-Martinez JR (1990) Chlorogenic acids and purine alkaloids contents of Maté (Ilex paraguayensis) leaf and beverage. Food Chem. 35:13-21.

Clifford MN; Ramirez-Martinez JR (1991a) Tannins in wet processed coffee beans and coffee pulp. Food Chem. 40: 191-200.

Clifford MN; Ramirez-Martinez JR (1991b) Phenols and caffeine in wet-processed coffee beans and coffee pulp. Food Chem. 40:35-42.

Clifford MN (1997) The nature of chlorogenic acids. Are they advantageous compounds in coffee? In: Proc. $17^{\text {th }}$ Int. Sci. Coll. Coffee (Nairobi), ASIC, Paris, pp.79-91.

Clifford MN (1999) Chlorogenic acids and other cinnamates. Nature, occurrence and dietary burden. J. Sci. Food Agric. 79:362-372.

Clifford MN (2000) Chlorogenic acids and other cinnamates - nature, occurrence, dietary burden, absorption and metabolism. J. Sci. Food Agric. 80:1033-1043.

Clifford MN (2003) Hierarchical Scheme for LC-MS n Identification of Chlorogenic acids. J. Agric. Food. Chem. 51: 2900-2911.

Clifford MN; Knight S; Sururu B; Kuhnert N (2006) Characterization by LC-MS ${ }^{n}$ of four new classes of chlorogenic acids in green coffee beans: dimetoxycinnamoyilquinic acids, diferuloylquinic acids, caffeoyl-dimethoxycinnamoylquinic acids and feruloyl- dimethoxycinnamoylquinic acids. J. Agric. Food. Chem. 54:1957-1969.

Correia AMNG; Leitão MCA; Clifford MN (1995) Caffeoyil-tyrosine and Angola II as characteristic markers for Angolan robusta coffees. Food Chem. 53:309-313.

Del Moral R (1972) On the variability of chlorogenic acid concentration. Oecologia 9:289-300.
Del Castillo MD; Ames JM; Gordon M (2002) Effect of roasting on the antioxidant activity of coffee brews. J. Agric. Food Chem. 50:3698-3703.

Deshpande SN; Aguilar AA (1975) Effects of roasting temperatures and gamma irradiation on the content of chlorogenic acid, caffeic acid, and soluble carbohydrates of coffee. Int. J. Appl. Rad. Isotop. 26:656-661.

Douglas CJ (1996) Phenylpropanoid metabolism and lignin biosynthesis: from weeds to trees. Trends Plant Sci. 1: 171-178

Farah A; Neves DF, Trugo LC; Rosenthal A; Della Modesta RC (2001) Compostos fenólicos em café torrado. In: Annals of the II Simpósio de PNP\&D Embrapa Café. Vitória, ES, pp.1144-1149.

Farah A (2004) Distribuição nos grãos, influência sobre a qualidade da bebida e biodisponbilidade dos ácidos clorogênicos do café. Instituto de Química, Universidade Federal do Rio de Janeiro, Brasil. Doctorate Thesis.

Farah A; De Paulis T; Trugo LC; Martin PR (2005a) Effect of roasting on the formation of chlorogenic acid lactones. J. Agric. Food Chem. 53:1505-1513.

Farah A; Monteiro MC; Trugo LC (2005b) Distribuição de ácidos clorogênicos nos principais defeitos do café. In: Annals of the IV Simpósio de PNP\&D Embrapa Café. Londrina, P.R., Brazil. (CDrom)

Farah A; Monteiro MC; Calado V; Franca A; Trugo LC (2006a) Correlation between cup quality and chemical attributes of Brazilian coffee. Food Chem. 98:373-380.

Farah A; de Paulis T; Moreira DP; Trugo LC; Martin PR (2006b) Chlorogenic acids and lactones in regular and water-decaffeinated arabica coffees. J. Agric. Food Chem. 54:374-381.

Ferreira LAB; Vilar H; Fragoso MAC; Aguiar MC; Cruz MJR; Gonçalves MM (1971) Subsídios para a caracterização do grão de café do híbrido de timor. In: Proc. $5^{\text {th }}$ Int. Sci. Coll. Coffee (Lisboa) ASIC, Paris, pp.128-147.

Flores-Parra A; Gutierrez-Avella DM, Contreras R, KhuongHuu F (1989) 13C and 1H NMR investigations of quinic acid derivatives: Complete spectral assignment and elucidation of preferred conformations. Mag. Reson. Chem. 27:544-555.

Franca AS, Oliveira L; Mendonça JCF; Silva X (2004) Physical and Chemical attributes of defective crude and roasted coffee beans. Food Chem. 90:84-89.

Ginz M; Enhelhardt UH (1995) Analysis of Bitter fractions of Roasted Coffee by LC-ESI_MS-New Chlorogenic acid derivatives. In: Proc. 16 ${ }^{\text {th }}$ Int. Sci. Coll. Coffee (Kyoto) ASIC, Paris.

Grace SC; Logan BA; Adams III WW (1998) Seasonal differences in foliar content of chlorogenic acid, a phenylpropanoid antioxidant, in Mahonia repens. Plant Cell Environ. 21:513-521.

Gross GG (1981) Phenolic acids. In: Conn EE (ed), The Biochemistry of Plants, Vol 7, pp.301-316. Academic Press, London. 
Guerrero G; Suárez M; Moreno G (2001) Chlorogenic acids as a potential criterion in coffee genotype selections. J. Agric. Food Chem. 49:2454-2458.

Haard NF; Chism GW (1996) Characteristics of edible plant tissues. In: Fennema OW (ed), Food Chemistry, $3^{\text {rd }}$ edition, pp.944-1011. Marcel Dekker Inc, New York.

Hermann KM (1995) The shikimate pathway as an entry to aromatic secondary metabolism. Plant Physiol. 107:7-12.

Hucke J; Maier HG (1985) Chinasaurelacton im Kaffee. Z. Lebensm. Unters. Forsht. 180:479-484

Ky C-L; Noirot M; Hamon S (1997) Comparison of five Purification Methods for chlorogenic acids in green coffee beans (Coffea sp.) J. Agric. Food Chem. 45:786-790.

Ky C-L; Louarn, Dussert S; Guyot B; Hamon S; Noirot M (2001) Caffeine, trigonelline, chlorogenic acids and sucrose diversity in wild Coffea arabica L. and C. canephora P. accessions. Food Chem. 75:223-230

Leloup V; Louvrier A; Liardon R (1995) Degradation mechanisms of chlorogenic acids during roasting. In: Proc. $16^{\text {th }}$ Int. Sci. Coll. Coffee (Kyoto) ASIC, Paris, pp.192-198.

Maier HG (1994) Status of research in the field of non-volatile coffee components. In: Proc. $15^{\text {th }}$ Int. Sci. Coll. Coffee (Montpellier), ASIC, Paris, France, pp.567-576.

Malta MR; Nogueira FD; Gimarães PTG (2003) Composição química, produção e qualidade do café fertilizado com diferentes fontes e doses de nitrogênio. Ciênc. Agrotec. Lavras. 27:1246-1252.

Manach C; Scalbert A; Morand C; Rémésy C; Jimenez L (2004) Polyphenols: food sources and bioavailability. Am. J. Clin. Nutr. 79:727-747.

Maria CB; Trugo LC; Moreira RFA; Werneck CC (1994) Composition of green coffee fractions and their contribution to the volatiles profile formed during roasting. Food Chem. 50:141-145.

Materska M; Perucka I (2005) Antioxidant Activity of the main phenolic compounds isolated from hot pepper fruit (Capsicum annuum L.) J. Agric. Food Chem. 53:1750-1756.

Mazza G; Miniati E (1993) Anthocyanins in fruits, vegetables and grain. CRC Press, Boca Raton.

Mazzafera P (1997) Maté drinking: caffeine and phenolic compounds. Food Chem. 60:67-71.

Mazzafera P (1999) Chemical composition of defective coffee beans. Food Chem. 64:547-554.

Mazzafera P; Robinson SP (2000) Characterization of polyphenol oxidase in coffee. Phytochemistry 55:285-296.

Menezes HC (1994a) Variação dos monoisômeros e diisômeros do ácido cafeoilquínico com maturação do café. Universidade de Campinas, Campinas, SP, Brasil. Doctorate thesis.

Menezes HC (1994b) The relationship between the state of maturity of raw coffee beans and the isomers of caffeoyilquinic acid. Food Chem. 50:293-296.

Merrit and Proctor (1959) Effect of temperature during roasting cycle on selected components of whole bean coffee. Food Res. 24:672-80.

Milderm IEJ; Feskens EJM; Arts ICW; Mesquita BB; Hollman PCH; Kromhout D (2005) Intake of the plant lignans secoisolariciresinol, matairesinol, lariciesinol and pinoresinol in dutch men and women. J. Nutr. 135:1201-1207.

Montavón P; Duruz E; Rumo G; Pratz G (2003) Evolution of green coffee protein profiles with maturation and relationship to coffee cup quality. J. Agric. Food Chem. 51: 1328-2334.

Moreira RFA, Trugo LC, Maria CAB (2000) Compostos voláteis de café torrado. Parte II. Compostos alifáticos, alicíclicos e aromáticos. Quím. Nova 23:195-201.

Moreira DP; Monteiro MC; Ribeiro-Alves M; Donangelo CM; Trugo LC (2005) Contribution of chlorogenic acids to the iron-reducing activity of coffee beverages. J. Agric. Food Chem. 53:1399-1402.

Monteiro MC; Trugo LC (2005) Determinação de compostos bioativos em amostras comerciais de café torrado. Quím. Nova 28:637-641.

Murata M; Okada H; Homma S (1995) Hydroxycinnamic acid-derivatives and p-coumaroyil-(L)-tryptophan, a novel hydroxycinnamic acid-derivative, from coffee beans. Biosc. Biotech. Biochem. 59:1887-1890.

Natella F; Nardini M; Gianetti I; Dattilo C; Scaccini C (2002) Coffee drinking influences plasma antioxidant capacity in humans. J. Agric. Food Chem. 50:6211-6216.

Nogueira M; Trugo LC (2003) Distribuição de isômeros de ácido clorogênico e teores de cafeína e trigonelina em cafés solúveis Brasileiros. Ciênc. Tecnol. Alim. 23:296-299.

Oliokpehai O (1982) Chlorogenic acid content of green coffee beans. University of Surrey, UK. PhD thesis.

Ohiokpehai O; Brumen G; Clifford MN (1982) The chlorogenic acids content of some peculiar green coffee beans and the implications for beverage quality. In: Proc. $10^{\text {th }}$ Int. Sci. Coll. Coffee (Salvador) ASIC (Paris), pp.177-185.

Pennycooke JC; Cox S; Stushnoff C (2005) Relationship of cold acclimation, total phenolic content and antioxidant capacity with chilling tolerance in petunia. (Petunia $x$ hibrida); Environ. Exp. Bot. 53:225-232.

Pereira AS; Pereira AFM; Trugo LC, Neto FRA (2003) Distribution of quinic acid derivatives and other phenolic compounds in Brazilian propolis. Z. Naturforsch. 58c: 590-593.

Rees DI; Theaker PD (1977) High pressure liquid chromatography of chlorogenic acid isomers in coffee. In: Proc. $8^{\text {th }}$ Int. Sci. Coll. Coffee (Abidjan) ASIC, Paris, pp.79-84.

Roffi J; Santos AC; Mexia JT; Busson F; Maigrot M (1971) In: Proc. $5^{\text {th }}$ Int. Sci. Coll. Coffee (Lisboa) ASIC, Paris, pp.179-200.

Scalbert A; Johnson IT; Saltmarsh M (2005) Polyphenols: antioxidants and beyond. Am. J. Clin. Nutr. 81(suppl): 215S-217S.

Schrader K; Liehne A; Engelhardt UH; Maier HG (1996) Determination of chlorogenic acid with lactones in roasted coffee. J. Sci. Food Agric. 71:392-398.

Scholz BM; Maier HG (1990) Isomers of quinic acid and quinide in roasted coffee. Lebensm. Unters. Forsch. 190: 132-134. 
Scholz-Bottcher BM; Ludges E; Maier HG (1991) New stereoisomers of quinic acid and their lactones. Liebigs Ann. Chem. :1029-1036

Silva EB (1999) Fontes e doses de potássio na produção e qualidade de café provenientes de plantas cultivadas em condições edafoclimáticas. Universidade Federal de Lavras, Lavras, MG, Brasil. Doctorate thesis.

Steinhart H; Luger A (1997) An analytical Distinction between untreated and steam-treated roasted coffee. In. Proc. $17^{\text {th }}$ Int. Sci. Coll. Coffee (Nairobi) ASIC, Paris, pp.155-160.

Takahama U (2004) Oxidation of vacuolar and apoplastic phenolic substrates by peroxidase: Physiological significance of the oxidation reactions. Phytochem.Rev. 3:207-219.

Tono T; Fujita S; Kawabe M (1989) Determination of chlorogenic acid in coffee samples by difference spectral method and DEAE-Toyopearl column chromatography. Nippon Shokuhin Kogyo Gakkaishi 36:587-591.

Trugo LC (1984) HPLC in coffee analysis. University of Reading, England. Doctorate thesis.

Trugo LC; Macrae R (1984a) A study of the effect of roasting on the chlorogenic acid composition of coffee using HPLC. Food Chem. 15:219-227.

Trugo LC; Macrae R (1984b) Chlorogenic acid composition of Instant coffees. Analyst 109:263-266
Trugo LC (2001) Café: Composição química e potencial nutracêutico. Ciência de Alimentos: avanços e perspectivas. Vol. II. In: Mercadante AZ et al (eds) Universidade de Campinas, Campinas, SP, Brasil.

Trute A; Gross J; Mutschler E; Nahrstedt A (1997) In Vitro antispasmodic compounds of the dry extract obtained from Hedera helix. Planta Med. 63:125-9

Ulloa Rojas JB; Verreth JAJ; van Weerd JH; Huisman EA (2002) Effect of different chemical treatments on nutritional and antinutritional properties of coffee pulp. Anim. Feed Sci. Technol. 99:195-204.

Ulloa Rojas JB; Verreth JAJ; Amato S; Huisman EA (2003) Biological treatments affect the chemical composition of coffee pulp. Bioresource Technol. 89:267-274.

Van der Stegen GHD; Van Duijn J (1980) Analysis of chlorogenic acids in coffee. In: Proc. $9^{\text {th }}$ Int. Sci. Coll. Coffee (London) ASIC, Paris, pp.107-112.

Variyar PS; Ahmad R; Bhat R; Niyas Z; Sharma A (2003) Flavoring components of raw monsooned arabica coffee and their changes during radiation processing. J. Agric. Food Chem. 51:7945- 7950.

Zeller BL; Saleeb (1977) Caffeine-caffeic acid complex formation in coffee extracts In: Proc. $17^{\text {th }}$ Int. Sci. Coll. Coffee (Nairobi) ASIC, Paris, pp.261-267. 